\title{
Mining and indigenous rights in Sweden: what is at stake and the role for legislation
}

\author{
Håkan Tarras-Wahlberg ${ }^{1}\left[\right.$ D $\cdot$ John Southalan ${ }^{2}$ (D)
}

Received: 10 March 2021 / Accepted: 23 July 2021 / Published online: 30 August 2021

(c) The Author(s) 2021

\begin{abstract}
Mining and the permitting process for mineral projects in Sweden has been criticised as inadequately safeguarding the rights of Indigenous reindeer herding Sámi, who hold usufruct rights to more than half the country's territory. There have been calls for Sweden to ratify the Indigenous and Tribal Peoples Convention (ILO 169) and to change its Mineral Law. This paper evaluates the extent of protection of Sámi rights — and not only those engaged in reindeer herding — in Sweden's minerals permitting process. It also considers the implications if changes were made to align this process with the Indigenous-rights framework. The paper demonstrates that reindeer herding Sámi are, broadly, treated similar to landowners in the mineral projects permitting process. However, there is discrimination when it comes to being able to have a share in the benefits of a project: impacted reindeer herders have no such option whereas landowners do. Also, the permitting processes do not consider social and cultural impacts, nor are there obligations for the state to be sufficiently involved in consultation processes. Addressing the identified shortcomings would require only small changes to the Mineral Law and/or to its application and would be possible with only limited impacts on mining because the sector is not a significant user of land whilst it creates large economic values. However, extending those changes (to give parity between landowners and Sámi rights holders) in other important economic sectors which use more extensive land areas, would entail a considerable transfer of resources and associated power. Furthermore, changing the Mineral Law specifically would mean little in terms of safeguarding the rights of the majority of Sami who do not engage in reindeer herding. This suggests that calls for changes to mineral-related legislation to resolve indigenous land right issues are mis-directed or at least insufficient, and that other type of legislative change is required, fundamentally including resolving how extensive and strong the Sámi's rights to land should be.
\end{abstract}

Keywords Mining $\cdot$ Sami $\cdot$ Indigenous rights $\cdot$ Sweden

\section{Introduction}

Conflicts between the extractive sector and indigenous peoples have long been a subject of study and interest, and initially most researchers focused on the Americas, South East Asia and Australia (Downing et al. 2002; Warden-Fernandez 2001). But in more recent times, the geographical focus has widened to also include the Nordic countries and Sweden which is the subject of this paper (Carstens 2016; Lassila

Håkan Tarras-Wahlberg

hakantw@gmail.com

1 Centre for Energy, Petroleum and Mineral Law and Policy, University of Dundee, Dundee, UK

2 University of Western Australia, Perth, Australia
2018; Lawrence and Moritz 2019; Persson et al. 2017; Raitio et al. 2020; Wilson 2019).

The international recognition of indigenous peoples' rights has increased in recent decades. The most important guiding documents on the state's responsibilities in this regard include the Convention concerning Indigenous and Tribal Peoples in Independent Countries (ILO 169 1989) and the United Nations Declaration on the Rights of Indigenous Peoples (UNDRIP 2007). Other UN instruments of relevance include the Covenants on Civil and Political Rights (ICCPR 1976) and the Elimination of All Forms of Racial Discrimination (ICERD, 1969), as well as the Declaration on the Rights of Persons Belonging to National or Ethnic, Religious and Linguistic Minorities (1992). Further, the scope of indigenous rights as defined in these UN treaties is addressed in the UN Guiding Principles on Business and Human Rights (UN 2011), which extends the 
responsibility for safeguarding indigenous rights to companies and businesses.

Sweden often promotes human and indigenous rights internationally. Sweden voted in favour of UNDRIP at the UN General Assembly in 2007 and is a signatory to both ICCPR and ICERD. Sweden is, however, not a signatory to ILO169, and the country has also received significant international criticism regarding indigenous and minority rights-related issues (see "International assessments of Sweden" section below). Sweden's apparent reticence in implementing key parts of the international rights framework "at home" for its indigenous Sámi represents a conundrum for some researchers (e.g. Lawrence and Moritz 2019; Mörkenstam 2019). In this regard, conflicts between mining and Sámi rights have attracted particular interest. Mining has been characterised as a method for colonisation (Lawrence and Åhrén 2017), whilst others have reported a lack of adequate consultation with Sámi in the permitting process (Lawrence and Moritz 2019). Conflicts that relate to specific mining projects and appeals by Sámi rights holders have been delaying permitting processes for mining projects (Beland Lindahl et al. 2016; Persson et al. 2017), and the Sami parliament of Sweden has also called for a moratorium for new mineral exploitation until such a time that ILO169 is ratified (Sametinget 2014). This, in turn, has contributed to calls for changes to be made to the mining legislative framework by researchers (e.g. Kløcker Larsen et al. 2018; Raitio et al. 2020) and more generally contributed to the government assessing the consequences of implementing stronger rights for the Sámi (SWE Gov 2015; SWE Gov 2019). Much of the focus of researchers and Sami representatives in this regard is placed on arguing that Sweden should ratify ILO169 and change its Mineral Law (SFS 1991; Kløcker Larsen et al. 2017; Sametinget 2014), rather than proposing wider legal reforms of the legal system. Furthermore, there has been comparatively less consideration for what the political stakes and full consequences of such proposed changes might be.

This paper aims to:

(i) Investigate the extent to which indigenous rights particularly as defined by UNDRIP and ILO169 - is provided for in the current Swedish minerals permitting process and the associated implications

(ii) Consider the stakes if Sweden was to fully implement the international indigenous rights framework - and thereby better understand the reticence by government in doing so, with a special focus on mining

Based on our findings in this regard, we also consider how Sweden could approach implementing an indigenousrights framework in relation to mining specifically, but also in more general terms. However, as the focus is on the Mining Law and indigenous rights, other legal instruments of relevance are treated more cursorily.

Our analysis focusses on the mining permitting process because, in Sweden, this includes the important aspects of consultation, establishes the mechanisms for compensation, and also the allocation of land for mining. We thus compare the procedural rights of the indigenous Sámi to that of other relevant stakeholders in the permitting process for mineral projects. Second, we assess whether the protection of Sámi interests in these processes is in line with the existing international indigenous rights framework more broadly. We further examine what the political stakes and consequences of any reform which align Sweden with the indigenous rights framework, specifically for the Sámi and the mining sector but also more generally, in an effort to better understand the apparent reservations of the Swedish state to fully implement said framework. This is performed by exploring some key data sourced from publicly available sources that relate to land use, and to the relative economic importance of different sectors of the national economy, and by studying relevant research that relates to impacts on reindeer herding activities by other anthropogenic activities.

\section{Existing standards and procedures}

\section{Relevant international standards and practice}

Contemporary international approaches to mining regulation emphasise the importance of the state achieving a balance between the benefits and impacts of mining. Significantly, the emphasis is not about structuring the community/society role to enable mining, but rather structuring mining to contribute to the community/society. This is evident in recent industry, international and academic guidance around mining. By way of example, a 2016 framework from the OECD about extractives projects identified the first step, for collaboration between the state, the sector and civil society, being to identify "a comprehensive long-term vision and implementation strategy to build competitive and diversified economies and create in -country shared value out of natural resources" (OECD 2016a, 10). More recently, in 2020, the OECD issued Guiding Principles for Durable Extractive Contracts. The first (of eight) principles is that "durable extractives contracts are aligned with the long-term vision and strategy, defined by the host government on how the extractive sector can fit into and contribute to broader sustainable development objectives" (OECD 2020,2). This type of approach is repeatedly emphasised in other guidance, from: 
- The mining industry (e.g. Mining Association of Canada (MAC 2019) and International Council on Mining and Metals (ICMM 2020))

- Inter-governmental and international guidance on mining (e.g. IGF (2013); UNEP (2018); UNDP (2018); International Resource Panel (2020))

- Academic and practitioner expertise, e.g. the 2014 Natural Resources Charter from the Natural Resource Governance Institute (NRGI 2014)

In this paper, we are concerned with the international indigenous rights framework, which forms part of the general UN led framework of universal human rights. One way of understanding how indigenous rights relate to more general human rights is defined by the Danish Institute for Human Rights (DIHR 2019, 5) where it is stated that indigenous peoples' rights are not "special rights that are exclusive to indigenous peoples. Rather, they are the articulation of universal human rights as they apply to indigenous peoples" with the aim to "ensuring equality between indigenous peoples and other sectors of society".

The two international standards most directly relevant to Indigenous-mining issues are ILO169 and UNDRIP. As at July 2021, 24 countries had joined ILO160, making it binding on them in international law. When the UN General Assembly adopted UNDRIP in 2007, four countries with well-established domestic legal regimes concerning indigenous rights opposed this: Australia, Canada, New Zealand and the USA. ${ }^{1}$ Each State has since withdrawn their initial opposition, with various caveats (Anaya and RodríguezPiñero 2018, 60), but are not necessarily incorporating UNDRIP domestically. This indicates some unease about the consistency and relation between their domestic systems and UNDRIP.

In relation to indigenous rights, UNDRIP and ILO169 have been considered in the development of standards in other documents, such as OECD Guidelines on Multinational Enterprises and also those that are concerned specifically with mining (e.g. ICMM 2015; IFC 2012; World Bank 2016). These assist in summarising the main requirements in international law and practice regarding mining and interaction with indigenous rights to land and resources.

UNDRIP and ILO169 include several articles that relate to indigenous people's right to self-determination, and control of their lands and territories or resources that they have traditionally owned or occupied. It is stated in both documents that no dispossession or relocation may occur without just and fair compensation and redress. Article 15 in ILO

\footnotetext{
${ }^{1}$ Each specifically explained their opposition at the time to the UN, referencing a perceived incompatibility of FPIC with their domestic legal and democratic systems (UN 2007), 11-15.
}

169 is especially relevant to mining in that it stipulates that indigenous people's rights to natural resources shall be specially safeguarded, and that: “.... in cases in which the State retains the ownership of mineral or sub-surface resources, governments shall establish or maintain procedures for consultation, with a view to ascertaining whether and to what degree their interests would be prejudiced, before permitting exploration or exploitation".

The aspect of UNDRIP which has received most attention relates to procedures for consultation, and it is the concept of "free prior informed consent" (or FPIC) and its implications for resource development (Coates and Favel 2016, 1). That is, regardless of any consultation obligations in ILO 169, UNDRIP outlines a requirement that activities which may affect indigenous people can only go ahead, with their prior free and informed consent. Importantly, the significance of impacts (to what extent an indigenous people is affected) are not considered or elaborated upon in UNDRIP.

FPIC is primarily a standard for states and to proceed with and/or give permission to a project without FPIC would require strong reasons indeed. According to the Special Rapporteur on the rights of indigenous peoples, James Anaya (UN 2013), such reasons include that (i) that it can be conclusively established that the activities will not substantially affect indigenous peoples' rights or (ii) where there is a valid public purpose, which in turn needs to be proportional to the limitations imposed, and must not include revenue raising or commercial interests. This, in turn, provides some guidance but at the same time requires careful consideration of what it means to "substantially affect indigenous peoples' rights".

FPIC has also become a standard for companies primarily through its adoption in specific instruments such as the IFC Performance Standards, ICMM's Mining Principles and various voluntary sustainability initiatives.

There is ambiguity in the international law regarding responsibilities concerning impacts on indigenous people. There is agreed wording about FPIC, but there is no consensus on what that means (or requires) in different situations. FPIC's most extensive enumeration is in UNDRIP, but there are two constraints on the extent of that legal guidance for countries. First, as a declaration, UNDRIP is not binding on nations. ${ }^{2}$ Conversely, it appears that FPIC is increasingly becoming an expected standard for companies, through its adoption in specific instruments such as the IFC Performance Standards, ICMM's Mining Principles and various voluntary sustainability initiatives, as well as to some extent from the implications of more general human

\footnotetext{
2 There is, of course, customary international law; and parts of UNDRIP are said to represent customary international law (and therefore describe obligations on states: e.g. (ILA 2012), [2]; (Anaya and Rodríguez-Piñero 2018), 62).
} 
rights standards as those laid out in guides from the OECD (OECD 2016b) and (OECD 2017). The second constraint on UNDRIP's FPIC text providing legal direction for nations is the "elusive language... [which represents] a compromise solution" evidently necessary to achieve sufficient support from the various parties: (Barelli 2018, 249); (Young 2019, 87-88); (Errico 2018, 426-437); (Charters 2018, 403).

For legally binding obligations on nations, these come from treaties/conventions. Most relevant here are the conventions on racial discrimination (especially regarding equality and property rights) and civil/political rights (especially concerning cultural rights). Treaty bodies, in explicating and implementing these conventions, have not provided a clear threshold for how significant an impact must be before it constitutes a breach in the absence of the relevant indigenous group's consent or adequate processes/remediation, e.g. Raitio et al. (2020, 5). For instance, the Committee on the Elimination of Racial Discrimination stated in 1997 that its treaty requires nations to "Ensure ... that no decisions directly relating to their [members of indigenous peoples] rights and interests are taken without their informed consent" (Gen Rec 23 CERD 1997, 4(d)). This was similar to the Human Rights Committee's statement in 1994 that its treaty provided that "The enjoyment of those [indigenous cultural] rights may require positive legal measures of protection and measures to ensure the effective participation of members of minority communities in decisions which affect them": (Gen Com 23 CCPR 1994, 7). However the jurisprudence from these bodies - their decisions concerning specific complaints - shows more nuance in what is (and is not) compliance. The relevant principles from these decisions are these.

- The protected cultural rights will be breached if a development threatens the way of life and culture of an Indigenous group (Ominayak -v- CAN 1990) [33], or has impacts which amount to a denial of the right (Länsman -v- FIN 1996) [10.3]. That impact may result from the combined effects of actions or measures over a period of time and in more than one area, making it necessary to consider the overall effects of any measures on the ability of the indigenous people concerned to continue to enjoy their culture (Länsman -v- FIN 2005) [10.2].

- It is a breach to endanger the very survival of the community and its members (Poma Poma -v- PER 2009) [7.6]. However measures that have limited impact on the way of life and the livelihood of indigenous persons will not necessarily constitute a breach (Länsman -v- FIN 1994) [9.4]. The question is whether the impact is so substantial that it does effectively deny the right to enjoy their cultural rights in that region (Länsman -v- FIN 1994) [9.5].

- Where an individual disputes state laws or measures which have been adopted for the preservation and well- being of group as a whole, those measure will not breach cultural human rights where the objectives and measures are reasonable (Kitok -v- SWE 1988, 9.8).

- The acceptability of measures that affect or interfere with the culturally significant economic activities of a minority depends on whether the members of the minority in question have had the opportunity to participate in the decision-making process in relation to these measures (Mahuika -v- NZL 2000) [9.5].

- Opportunity to participate involves more than just consultation, and where measures substantially compromise or interfere with culturally significant activities, this requires "not mere consultation but the free, prior and informed consent of the members of the community" (Poma Poma -v- PER 2009) [7.6].

It is difficult to fully reconcile or synthesise these various international standards and decisions. But it is necessary to attempt that, if international law is to help analyse and guide national laws and policies. Ambiguities around FPIC are not Sweden-specific and are widely acknowledged (e.g. (NOR NCP 2016, 15); (Raitio et al. 2020, 5); (Newman 2017, 12-16)). Our understanding of the relevant international law is this. The promotion and protection of indigenous rights have increased over time. Despite some uncertainty and disagreement about FPIC's application at its extremes, there are some generally-accepted basics when impartial evaluations are made as to whether the requirements of FPIC have been met. There is an emphasis on the process (consultation and its objective) not always an outcome (consent). There is, currently, an expectation that consent should be sought before any measures which may impact indigenous people. But, if that consent does not exist, an indigenous rights breach only arises where the measure significantly impacts the indigenous group's property or cultural rights. Failure to even attempt to reach consent has been identified as an indigenous rights breach, but only in cases where there was also significant impact (e.g. Poma Poma -v- PER (2009), Ågren -v- SWE (2020)). There is no precedent of a case adjudging a breach of indigenous rights where there was failure to attempt to reach consent and the measure had only limited impact.

Above, we summarised the essential requirements related to indigenous rights and associated procedures, and the question now is to what extent are these observed in the regulation of mineral projects in Sweden? To answer this question, we need to understand some basic facts about the Sámi, reindeer herding and mining, and how these are regulated, as well as how the international rights framework in more general terms is catered for in the Swedish legal system. 


\section{The Swedish Sámi and their rights}

Sweden has a civil law system, which like the other Nordic countries include significant aspects of common law (Ortwein, 2003). In contrast to some other European legal systems, there is no fundamental constitutional document based on a declaration of rights of citizens. The Instrument of Government most closely resembles such a document, and it provides that public power shall be exercised to ensure universal human equality and individual freedom and dignity. However, a wider (human) rights perspective has historically had comparatively little importance, and the regulatory system has been developed gradually and over a long period, mainly based on positivistic and pragmatic consideration (Axberger, 2018b). Axberger (2018b) argues that this is one of the main reasons why Sweden supports the human rights framework internationally as a way to pursue certain political goals, whilst at the same time being comparatively slow and/or in some cases unwilling to incorporate a (human) rights approach in domestic legislation. Sweden has a dualist system, which means treaties must be interpreted, adapted and transferred into national law, before implementation. Aspects of conventions that have not (yet) been incorporated in law, and even declarations can however be judged as being relevant in adjudications (Axberger, 2018a; Axberger, 2018b). However, if there is a conflict between an international convention and existing Swedish laws, the latter prevails in Swedish courts.

Swedish government policy precludes the possibility of ethnicity-based censuses, but existing estimates suggest that the Sámi number is between 20,000 and 35,000 (out of a Sweden's total population of 10 million). The history of the Sámi includes many negative aspects of colonisation and/or discrimination including examples of forced labour (notably when some Sami where obliged to transport ore from mines in the 1700s), cultural assimilation, forced relocation and racism (e.g. Lundmark 2008). However, there were also historic periods and aspects when the relationship between the Sámi, the Swedes and other minorities (notably the Tornedalians in northern Sweden, who also have been the subject to significant discrimination) was respectful and beneficial and when access to at least some land has been shared (e.g. Persson 2007).

Until fairly recently, Swedish policy towards the Sámi was rooted in the vestiges of racism and of an overarching intention that non-nomadic Sámi (as well as other minorities, such as the Tornedalians) should be assimilated, whereas nomadic Sámi should follow a separate and restricted development path based on traditional reindeer herding. It was only in the last few decades of the twentieth century that this discriminatory and colonial heritage began to be addressed in earnest. Thus, the Sámi was acknowledged as an "original population" of Sweden in 1976 (SWE Plmnt 1976), and rights to some self-determination has subsequently been introduced in an amendment to the constitution where it is stated that "opportunities shall be promoted for the Sámi people and for ethnic, linguistic and religious minorities to preserve and develop a cultural and social life of their own" (SWE Plmnt 2010).

A popularly elected Sámi parliament was inaugurated in 1993, although with a limited remit of monitoring and managing specific issues related to reindeer herding and Sámi culture, which does not reach the objective of providing any significant level of self-determination (e.g. Baer 2005). Furthermore, voter registration and turnout remain low, ${ }^{3}$ which affects legitimacy. Nevertheless, the progress made led to an official government report concluding that by 1999 , Sweden fulfilled "the requirements set out in the Convention (169) in most respects" (one would expect that this means that the Sámi has been afforded the basic indigenous rights including preservation of, language, religion, and cultural heritage), with the "main stumbling block being the rules concerning Sámi land rights": (SWE Gov 2015). The Swedish government has been preparing a legislative proposal for improved consultation with Sámi communities and organisations, in an attempt to address the requirements of FPIC (SWE Gov 2019).

Sweden's legal system has only traditionally recognised and protected Sami land rights when these rights are tied to reindeer herding. Only a small minority of the Sámi, namely those about 4,600 individuals that belong to a "sameby" (a cooperative organisation, that engages in reindeer herding), have rights to use land and to keep reindeer, whereas the majority of those with Sámi heritage have no such rights. However, they do indirectly, as it is stated in the constitution that: "the Sámi people's rights to perform reindeer herding is to be regulated through law". In essence, this means that whereas only the Sámi may engage in reindeer herding, relatively few of those with Sámi heritage actually do, and only some 2,500 individuals have reindeer herding as their main livelihood (Sametinget 2020).

Reindeer herding is pursued over extensive areas, covering nearly half of Sweden, and it is regulated by the Reindeer herding Law (1971:437) which divides the northern half of Sweden between 51 different samebyar (one sameby, several samebyar). These samebyar, in turn, each encompass geographical areas where reindeer may graze (pasture areas), a form of communal work arrangement and a business entity.

Sámi rights over land have been tried in important and landmark cases in the Swedish courts, including the High Court. Sami representatives have had some significant successes in this regard, and it has overall been established that

\footnotetext{
38,766 registered voters and a 58\% turnout in 2017 (Sametinget
} 2020). 
the rights of reindeer herding Sami to land (that is members of a sameby) are based on either use "from time immemorial" or through customary use. In the Nordmaling case (Nordmalingmålet, 2011), a group of landowners had initiated a case to stop three samebyar from using some specific parcels of land for winter grazing on the basis that these had not historically been used by the Sami. In the trials that followed, ending up in the High Court, the Sami representatives successfully proved customary use based on historic documents.

Sameby members also hold special rights to hunting and fishing within their pasture lands. A recent court case adjudicated that one northern sameby - Girjas - holds the exclusive right to hunting and fishing in the western part of their pasture lands, that they may control who can hunt and fish on these lands henceforth and that this right is not related to the provisions of the Reindeer herding Law, but to the use of land since time immemorial (Girjasmålet 2020). The consequences of this verdict to other areas, to other sectors of the economy or other activities in northern Sweden are as yet unclear. However, in common for all cases where the rights of the Sami have been considered is that the judicial reasoning is specifically tied to existing Swedish laws, although with some limited reference made to the international rights framework, for example, in the Girjas case. These developments have furthermore contributed to the government recently initiating a process of now reviewing the Reindeer herding Law.

The fact that only a minority of the Sámi may have reindeer herding as a livelihood has caused considerable conflict. An ongoing court case regarding the right to keep reindeer involves the Vapsten sameby (the same involved in the (Ågren -v- SWE 2020) case) and another group of Sámi - also named Vapsten and with historical links to the same area - is illustrative of the complexities that exist (Vapsten -v- Vapsten 2020). The district court initially adjudicated that both groups have equal rights to reindeer herding in the area, although the verdict was appealed, and the court of appeal ruled that the case should be reheard by the lower court.

In the main a sameby may not engage in any other activity or business that does not directly relate to reindeer husbandry, and it is not clear if a sameby can enter into contracts that in some way diminish/endanger the activity of reindeer herding itself (Torp 2018; Brännström and Allard, 2019). Individual members of a sameby may, however, engage in other activities in his/her own capacity. Substantial reindeer herding areas (some $25 \%$ of the total pasture areas) are protected through the Environmental Code (SFS 1998) as being "national interests", that should to the extent possible be protected. However, other land uses and/or features are also protected in this way (such as areas for leisure activities, environmental protection, military use and also including mineral deposits, see below), and situations where two or more such national interests' overlap are not uncommon. In cases where overlap occurs, the Environmental Code states preference for the land use that "best contributes to sustainable development".

\section{Mining and its regulation}

The Swedish mining sector is important, and especially so in the north where mining companies count among the largest employers and where mining is the fundamental reason for the existence of substantial cities (e.g. Kiruna and Gällivare).

It is not explicitly stated in law who owns precious minerals, referred to as "concession minerals" (e.g. see SWE Plmnt (2012)). However, given that the state grants the right to explore and exploit, the situation is similar to where minerals belong to the state. Mineral projects are regulated by the Mineral Law (SFS 1991), which provides security of tenure and which overall aims to enable the identification of concession mineral deposits and their subsequent extraction. The nature and content of the Mineral Law is in this way similar to that of most countries which have a substantial mining sector (Cameron and Stanley 2017, 72).

Permits for exploration and for mining are provided on a first-come, first-served basis, although there are some requirements for the applicant to have adequate ability to undertake the work, and not previously shown to be unsuitable in this regard (SFS 1991). Exploration may be conducted without a preceding Environmental Impact Assessment (EIA), although there is a requirement to have a work plan accepted before any significant work may start. Two main permits are required for mining: (i) an exploitation concession, granted by the Mining Inspectorate in accordance with the Mineral Law (SFS 1991), and with a requirement that the application includes a limited EIA which is performed to address land use related issues and specifically whether mining is an appropriate land use at the proposed location; and (ii) an environmental permit, granted by a Land and Environmental Court in accordance with the Environmental Law (SFS 1998). The latter permit is assessed on the basis of a comprehensive EIA.

In cases where relocation of people, business or buildings is required, this is addressed as part of the permitting process for an exploitation concession. Chapter 2 of the Law on Expropriation (SFS 1972) provides for the expropriation of land for businesses and/or activities that are of socalled national importance. However, mining is specifically excluded, and instead, the allocation of land for mining is treated in Chapter 9 of the Mineral Law in a so-called land designation process. In practice, this means that mining is provided with the same priority as land uses of national importance - but without the associated and explicit legal 
reasoning which exists in the Law on Expropriation. In the land designation process, a mutually acceptable settlement is explicitly encouraged by law, but in cases when no such settlement is possible, the Mining Inspector will decide the terms. The Mining Inspector's decisions are informed by the provisions in the Law on Expropriation.

As mentioned above, mineral deposits may be classified as being of "national interest", which means that such areas enjoy some level of protection from other land use proposals that would make future exploitation of the deposit impossible. Overall, there are no special requirements, taxes or fees that apply to mining and nor is there a royalty payable to the Swedish state (the state's revenue from mining is generated mainly through profit and income taxes). There is a "mineral fee", a unique feature for Sweden, ${ }^{4}$ and which comprises $0.02 \%$ of the value of production of which with $2 / 3$ is paid to the land owner (in cases when the concession is in an area which is owned by a party other than the concession holder) and $1 / 3$ to the state, ostensibly to be used to fund mineral related research (SWE Plmnt 2004).

\section{International assessments of Sweden}

There have been criticisms, from within the UN system, of Sweden's regulation of indigenous rights generally and also in relation to mining specifically. Examples from the UN's Human Rights Council include a 2016 report (UN 2016, 11-13), and numerous recommendations concerning Sami rights and ILO169 in the Universal Periodic Review (UN 2020, 10 \& 23).

The bodies which oversee the human rights treaties which Sweden has joined have raised concerns regarding the interaction between Sámi and mining rights, namely the Committee on the Elimination of Racial Discrimination (CERD); the Human Rights Committee (CCPR); and the Committee on Economic, Social and Cultural Rights (CESCR). The recommendations from these bodies constitute their guidance on what Sweden must do to comply with these treaties ((Concl Obs SWE CERD 2018) [16]-[17]; (Concl Obs SWE CCPR 2016) [38]-[39]; (Concl Obs SWE CESCR 2016) [13]-[14]). Relevant here, these have included that the Swedish nation should review its laws and procedures which may impact Sámi interests, including the Mineral Law, the Minerals Strategy and the Environmental Code; also that all Sámi, including non-reindeer herding Sámi, should enjoy equal access to water and land. These treaty bodies have also stated that Sweden should consider ratifying ILO 169. There is, however, ambiguity in how these bodies frame issues in relation to FPIC (and what that requires), evident in these three statements that Sweden should:

\footnotetext{
4 Though a similar mechanism exists in Finland.
}

- "[R]eview existing legislation, policies and practices regulating activities that may have an impact on the rights and interests of the Sámi people, including development projects and extractive industries operations, with a view to guaranteeing meaningful consultation with the affected indigenous communities aimed at attempting to obtain their free, prior and informed consent" (2016, Human Rights Committee, emphasis added).

- "Ensure, in law and in practice, that the necessary efforts are made to obtain the free, prior and informed consent of all Sámi people on decisions that affect them, and provide legal assistance in that regard" (2016, Committee on Economic Social and Cultural Rights, emphasis added)

- "Take measures to enshrine the right to free, prior and informed consent into law, in accordance with international standards" (2018, Committee on the Elimination of Racial Discrimination, emphasis added)

The Human Rights Committee's 2016 observations on Sweden provide the most relevant guidance here:

-Mining laws, policies and practices which may impact Sámi rights or interests of the Sámi people

-Should have "a view to guaranteeing meaningful consultation" with affected communities

-That consultation should be "aimed at attempting to obtain their free, prior and informed consent"

-To these three points (made specifically about Sweden) should be added a fourth that where a proposed development will significantly impact an indigenous group's rights, then their consent ought be obtained before proceeding - a position understood and advocated by the World Bank, International Council of Mining \& Metals and the Organisation for Economic Cooperation and Development, e.g. IFC (2012) [15] \& [12]; ICMM (2013, 4); $\operatorname{OECD}(2017,98)$.

It is, therefore, these four considerations (and not exclusively the presence or absence of consent) which should guide analysis or amendment of Sweden's mineral laws as regards Sámi rights. This is reinforced by a December 2020 decision of the Committee on the Elimination of Racial Discrimination which ruled Sweden in breach of its international obligations concerning its grant of mining-rights which would enable significant impacts on reindeer herding of the Vapsten reindeer herding cooperative (Ågren -v- SWE 2020). The decision recorded that there had been extensive consultation and review processes under Swedish law (both prior to and following the Government's grants) which addressed "some" impacts on reindeer herding and associated culture (summarised in (̊ggren -v- SWE 2020, 6.8-6.11)). However the Committee adjudged Sweden in breach in two key respects. 
- Inadequate consultation by the State (or ensuring that consultation would occur by the company). The Committee saw this as necessitating "consultations in good faith and with a view to reaching consensus" (6.17), and that "environmental and social impact studies should be part of the consultation process with indigenous peoples... conducted by independent and technically competent entities, prior to the awarding of a concession for any development or investment project affecting traditional territories" (6.18). The Committee rejected the argument that the Government could simply choose between competing activities on the basis of its view of public interest: "Development and exploitation of natural resources, as a legitimate public interest, does not absolve States parties from their obligation not to discriminate against an indigenous community that depends on the land in question by mechanically applying a procedure of consultation without sufficient guarantees or evidence that the free, prior and informed consent of the members of the community can be effectively sought and won" (6.20).

- Inadequate protection and remedies for the cultural rights impacted by the grant of the mining permits. The Committee explained the treaty against racial discrimination required that "where indigenous peoples have been deprived of lands and territories traditionally owned or otherwise inhabited or used without their free and informed consent, the State should take steps to return those lands and territories. Only when this is for factual reasons impossible should the right to restitution be substituted by the right to just, fair and prompt compensation, which should, as far as possible, take the form of lands and territories" (6.27).

\section{Sweden's mining procedures and indigenous rights}

Below, we investigate whether the rights of the Sámi are equal to that of other stakeholders in the permitting process for mineral projects and further whether the protection thus afforded is in line with applicable parts of the existing international indigenous rights framework more broadly, as described in "Existing standards and procedures" section.

\section{Sámi rights in the permitting process for mineral projects}

In Sweden, the issuance of exploration licenses is governed primarily by the Mineral Law, and licenses are generally issued if the application is concerned with ground which is "open" (that is exploration is allowed, and there is no existing mineral tenure) and if the applicant is deemed suitable and capable. However, the practice is that relevant land and stakeholders (including the relevant sameby and in also the Sámi Parliament) are informed and provided the opportunity to object to the application (SGU, 2016, 15). Furthermore, an approved work plan is required before any exploration work; and the relevant sameby and the Sámi Parliament are provided with an additional opportunity to comment and/or object before the workplan can be accepted (Ch 3, §5a, §5c). If there are objections, then consultations may be performed to achieve agreement. If no agreement is achieved, then the applicant may request the Mining Inspectorate to decide the matter without further consultation. Although there are limited opportunities to stop an exploration project, the Mining Inspector may decide that conditions be attached to the approved licenses and work plans (e.g. in practice, there are regularly requirements for posting a financial guarantee and there may be stipulations of when in the year specific activities can take place). In this respect, the situation for Sámi stakeholders is comparable to that of other users of land, whose consent is also not explicitly required (although negotiation is encouraged before exploration). Thus, consultation with the relevant sameby is required, and there is no significant and formal discrimination in how Sámi rights are addressed in the permitting of exploration licenses. And, given the nature of mineral exploration, such activities are unlikely to cause "significant impacts" or "substantially affect" indigenous peoples' rights.

The conditions for the application and issuance of mining licenses are mainly governed by the Mineral Law, but also by parts of the Environmental Act (namely Chapters 3 and 4 that are concerned with protected areas, and how to set priorities for land use, $\S 15$ of Chapter 5 which is concerned with impacts on water and Chapter 6 which contains provisions for the consultation to be performed). Thus, an application for a mining license requires an EIA to be performed, and in the northern half of Sweden, this EIA typically also specifically assesses impacts on reindeer herding, although it generally does not assess any social and cultural impacts. Allocation of land, and any resettlement and compensation issues are also considered and decided upon in the mining license application process, and not in the environmental permitting process (see below). This, in turn, means that mining license application process is crucial for reindeer herding and overall Sámi interests (Raitio et al. 2020).

The mining license permitting process includes requirements for the proponent to consult widely, including with the relevant sameby, and that the Sámi Parliament be informed. Both the sameby and the Sámi Parliament also have the right to appeal. There is evidence that project proponents have, of late, made stronger efforts to assess impacts on reindeer herding and suggest mitigating and/or rehabilitative measures in this regard (Kløcker Larsen et al. 2018; Tarras-Wahlberg 2014). However, although the relevant sameby must be consulted by the project proponent, and Swedish legal 
procedure provides them that right, they have of late often chosen not to participate in such processes (Kløcker Larsen et al. 2018). Furthermore, the requirement to consult with the sameby is directed towards the project proponent, and not the Swedish state.

A holder of a mining license may initiate a process for the designation of land rights for mining and associated activities (e.g. processing). As mentioned above, it is encouraged that the license holder negotiates with landowners and other rights holders (including the relevant sameby) in good faith to reach agreement. However, if no agreement is reached, then the Mining Inspectorate will decide land allocation (Ch 9, §2), as well as the associated levels of compensation which in turn are based on the expected impacts to the owner of the land and/or items to be compensated. For the sameby, the compensation will generally be related to compensation for economic damages caused and/or the loss of pastures. There is no avenue for obtaining compensation for any cultural and/or social impacts that may occur. If, once mining has started, the sameby finds that the compensation is inadequate, its sole legal avenue is to sue the mining company for damages in a civil court, and there are examples of such processes. ${ }^{5}$

The above suggests there is no significant and formal discrimination in how Sámi rights are addressed in the process for awarding a mining license. But, in line with the Ågren -v- Sweden decision, this may be insufficient as Sámi interests require "different" and special treatment compared to other property owners (see, i.e. 6.14-6.17). Furthermore, Lawrence and Moritz (2019) argue that the consultative initiatives undertaken by project proponents are insufficient to meet FPIC requirements as consent is not required (neither in law nor in practice), and the state has no role and/ or obligation to ensure that consent is sought. However, the latter does not negate the possibility that, even given current legislation and practice, there may be cases where sufficient consultation in line with FPIC may still have taken place, if the impacts on reindeer herding activities are not significant enough for consent to be required (see "Relevant international standards and practice" section above).

Another important objection to the existing permitting process could also be that the Sámi organisations (that is the relevant Sameby) invited to take part in the process may not accurately reflect the opinions and wishes of the larger Sámi community. This, in turn, is an issue that is not directly related to the Mineral Law but to more substantial and wider legal issues regarding the rights of the Sámi in Sweden.

\footnotetext{
5 Including compensation decided upon in court that relates to the Vapsten sameby, and two companies Lappland Goldminers (since bankrupt) and Dragon Mining; and where in both cases the courts ruled that further compensation be paid, although less than what Vapsten sued for.
}

National interest areas for minerals and reindeer herding may overlap, and in such cases Chapter 3 of the Environmental Code stipulates that the activity that best contributes to longer-term sustainable development should have precedence. This, in turn, leads to what have proven to be difficult judgements. The relevant authorities have in fact been unable to resolve these and in turn have referred them to central government for decision. ${ }^{6}$ Only one such judgement has actually been done, and it is the same project which became the subject of the Agren - $v$-Sweden decision, where the mining interest was deemed to have precedence largely because of its perceived socio-economic benefits, and with acknowledgement that reindeer herding over the specific area would be made impossible for an extended — although limited - period of time.

The Committee on the Elimination of Racial Discrimination subsequently found Sweden in breach (see "Relevant international standards and practice" section above), which leaves the situation of the company having complied and obtained permission within Swedish domestic law, but the Swedish state currently in breach of international law. The lack of any more examples negates the possibility of any wider evaluation of whether outcomes in this regard may be in line with international indigenous rights framework.

Overall many stakeholders have little to lose by opposing a mining project. This is the case for sameby, other Sámi, and indeed other local land owners. The government's general operations provide all Swedes, including the Sami, with the necessary public and/or other services, and these are not dependent on negotiations or agreements with resources projects or developers, e.g. UN (2013) [24]. Further, there is no tradition and/or legal stipulations that provide for communities and/or other stakeholders and resource developers negotiating for benefits to be associated with a specific project such as in countries where negotiations between project proponent and indigenous representatives may be concerned with increased local benefits (e.g. employment, business, services, as well as in some cases even basic services like education and health (e.g. Dupuy 2014)).

The international rights framework places significant importance on compensation and redress for impacts incurred (consider Ågren - v- Sweden 2020, 6.2.7) on indigenous rights holders. As shown above, these types of issues often form an important part of the interactions and overall relationships between mining (and other) companies and affected samebyar. The international rights framework also places significant emphasis on indigenous peoples being able to wherever possible, participate in the benefits of

\footnotetext{
${ }^{6}$ Several companies' applications for mining concessions are or have been considered by government in recent times, including those of Nickel Mountain, Jokkmokk Iron, Vilhelmina Mineral and Boliden.
} 
Table 1 Comparisons of land use, and pertinent financial data in mining, exploration, forestry, wind power and reindeer herding

\begin{tabular}{|c|c|c|}
\hline & $\begin{array}{l}\text { Area } \\
\left(\mathbf{k m}^{2}\right)\end{array}$ & $\begin{array}{l}\text { Indicator of } \\
\text { GDP/turnover } \\
\text { (MSEK) }\end{array}$ \\
\hline Mining land use (active mines) & $197^{1}$ & $25,523^{5}$ \\
\hline Exploration & $9514^{1}$ & $772^{6}$ \\
\hline Forestry & $235,030^{2}$ & $33,940^{5}$ \\
\hline Wind power: & & n.d \\
\hline commissioned & $2,250^{3}$ & \\
\hline permitted & $1,560^{3}$ & \\
\hline $\begin{array}{l}\text { Reindeer herding pastures, total } \\
\text { of which, "from time immemorial" }\end{array}$ & $\begin{array}{l}256,943^{4} \\
101,856\end{array}$ & $230^{7}$ \\
\hline
\end{tabular}

${ }^{1}$ Land use and areas under exploration permits 2018 (SGU 2020); ${ }^{2}$ land use 2015 (SCB 2020); ${ }^{3}$ land use 2020 (Energimyndigheten 2020); ${ }^{4}$ land use 2019 (Sametinget, 2020) — note that all this area is not possible to use for reindeer herding, due to incompatibility with other land users and overall fragmentation of the landscape (Österlin and Raito, 2020); ${ }^{5} \mathrm{GDP}$ (production side) 2017 (SCB 2020); ${ }^{6}$ exploration expenditure 2018 (SGU 2020); ${ }^{7}$ total turnover of reindeer herding cooperatives/samebyar, 2019 (Samer 2020).

mineral projects. There is no royalty stipulated in the Mineral Law, but landowners may either obtain the mineral fee, or - in addition to compensation to any damage caused - have the opportunity to strike a deal with the project proponent to sell or lease the land or, if this is not possible, be compensated for their land in a process which is led by the Mining Inspector. ${ }^{7}$ The sameby have no such formal legal possibility and thus have little to gain financially from welcoming a mineral project on their pasture lands, as the best it can hope for is compensation for foreseen impacts decided upon by the Mining Inspector, any further damages that it may obtain through civil court action and/or any further compensation that the mining company may agree with on a voluntary basis.

This situation is not only discriminatory, but it may also contribute to the present situation where the Sámi Parliament and affected samebyar seldom find good reason to welcome and/or accept mining related projects, even if the effects on both local communities and wider society may appear to be beneficial.

In this aspect, where essentially all projects meet with resistance from the Sámi, mining differs from other sectors and land uses in northern Sweden. For example, the forestry sector and the relatively newer wind power sector are performed over areas that are much larger than those used for mining (see Table 1). One author's experience in, and

\footnotetext{
${ }^{7}$ Note that this process is not governed by the Law on Expropriation (SFS 1972), as mining is specifically excluded from consideration in that law.
}

knowledge of, land and resources issues in Sweden over the past 15 years has shown that forestry and wind operations - although sometime also the subject of Sámi protest and objections - have had comparatively greater success (than mining) in engaging with Sami and reaching agreements about land access and operations (H. Tarras-Wahlberg, pers. comm.). Their relative greater success in being able to use land in reindeer herding areas have different reasons. One fundamental aspect is likely to be the fact that both forestry and windfarms rely on a priori land ownership - which is difficult to challenge through legal means - rather than being reliant on obtaining concessions from the state, and then being designated land. The success of forestry in this regard is also likely due to it being possible to use the same land for both mining and reindeer herding (albeit that forestry is known to have significant impacts (e.g. Berg et al. 2008). It is furthermore probably related to the existence of large number of private forest owners - so not only is the sector important economically (on par with mining), it also has a large support among wider society and is politically difficult to resist. Wind power similarly enjoys strong political support, and further, as such projects are privately led endeavours that do not involve a state-controlled commodity, it may be easier for project proponents to propose attractive commercial terms to other land users and/or owners.

In the next section, we consider what the stakes are for existing land users in northern Sweden, with a special focus on mining, if more effective measures to safeguard indigenous rights were implemented more fully through, for example, the ratification and implementation of ILO169.

\section{The interests and implications around change}

The analysis above suggests that in the main, the rights of the reindeer herding Sámi are not given comparatively lesser weight or being discriminated against compared to other land right holders in the mineral exploration permitting process. This conclusion may be surprising to some but is a reflection of the nature of the Mining Law. Sweden, like many countries, has a mining law which encourages mining (through private rights of exploration and extraction) frequently prioritising these over other uses of land (e.g. Southalan (2012, 47-49)). Sweden's mining law aims to ensure that exploration and possible subsequent mining for concession minerals be made possible even in places where landowners and land right owners oppose such activities. The reason why such a law exists is that economical deposits of precious minerals are rare - which necessitates exploration over extensive areas - and that the values generated by mining such deposits can be very significant, and therefore it is seen to be in society's best interest that they be exploited. That still holds, but more recent international practice and guidance emphasises the importance of 
sustainable development, and therefore greater attention to social and environmental aspects as well as financial returns.

However, samebyar do not have legal possibilities of sharing the benefits of mining - by being a partner in a project, receiving a mineral fee, having the possibility of striking a deal with the mine proponent for relinquishment of land use rights or at the very least to be formally expropriated. The best they can hope for is to through the permitting process be compensated for impacts caused, or through a mining company agreeing to compensate in excess of this through a voluntary initiative, and/or - as a last resort - sue a mining company for identified damages caused once project has been initiated. Similarly, the Sámi Parliament (and by inference non reindeer herding Sámi) do not receive any direct benefits from allowing a mining project to go ahead.

So, what would be the impact if existing Sámi right holders (that is the reindeer herders, through the samebyar) were given the same rights as landowners in the permitting processes? In evaluating this, it is important to establish that the areas we are considering are large. This, in turn, follows as reindeer herding as an important part of Sámi livelihood and culture has long enjoyed significant levels of acceptance and legal protection, with the result that reindeer herding Sámi's rights to pasture lands are extant over most of their historical lands which, in turn, cover slightly more than half of Sweden's territory (see Table 1 below). Thus, in contrast to most other countries with colonial history, there has not been any spatially significant extinction of indigenous land use rights in Sweden, although as the existing rights are nonexclusive (usufruct), there has been a significant reduction in the level of Sámi control of the land furthermore, some of this land cannot be used for reindeer herding for various reasons, including other and incompatible land uses (e.g. cities, industries, infrastructure, power generation etc.). The Swedish situation also differs to that of Norway and Finland, where Sami rights have been provided with relative greater importance in certain areas where Sami make up a comparatively larger proportion of the inhabitants (i.e. in Finnmarka Norway and in three northern municipalities in Finland).

Nevertheless, the impact of Sámi right holders being were given equal rights as landowners in the permitting processes for mining, as it is currently regulated, would probably be insignificant. This follows from the fact that whilst the currently active mines generate substantial values, they use only comparatively small areas $\left(197 \mathrm{~km}^{2}\right.$ in total designated for active mines and actual land used less than that, Table 1), although the impacts stretch beyond those immediate areas, with estimates of avoidance zones for reindeer caused by mining ranging - depending on specific circumstances from 1-2 km around smaller mines in forests (Johnson et al., 2015; Polfus m.fl., 2011) up to 11-14 km around large open pit mines on the Arctic tundra (Boulanger et al., 2012). In all, this means that the commercial value of the land used and the size of compensation to be paid for other associated impacts are unlikely to be large in comparisons to the values generated. ${ }^{8}$ Similarly, for mining operations to pay mineral fees also to Sámi right holders would entail comparatively small sums of money (the total mineral fee was SEK12 million in 2017).

The set up alluded to above - with Sámi reindeer herders and landowners given parity in the mineral legislation - may well find support within wider Swedish society. For Sámi stakeholders, thus, the mining sector need not necessarily be seen as a significant adversary in their struggle for better recognition of land rights.

The same does not hold true for other land users and important parts of the economy in northern Sweden. To provide Sámi right holders equal rights as land owners in areas where both forestry and reindeer herding is undertaken (likely to be well over $100,000 \mathrm{~km}^{2}$ and held by numerous different land owners; see Table 1) or where wind power projects have been implemented in reindeer herding areas (likely more than $1,000 \mathrm{~km}^{2}$, and growing; see Table 1) would entail the transfer of sizeable wealth and associated power to a relatively small number of individuals who are member of a sameby (some 4,600 individuals), and such a measure may also struggle to obtain wider societal support.

\section{Conclusions}

Swedish Sámi reindeer herdes have usufruct rights to extensive land areas. In relation to mineral exploration activities, these usufruct rights have similar protections as those of landowners, both in terms of consultation requirements and compensation for economic damages that may be caused. Thus, the reindeer herding Sámi are, in the main, not treated worse than landowners in the mineral exploration permitting process. The consultative procedures that are in place address some aspects of the international rights framework, but not all aspects of FPIC. Consent is not required (under Swedish law), and the requirements that exist in terms of consultation are directed towards project proponents rather than the state. However, where exploration activities are unlikely to cause significant impacts on Indigenous parties, there is no international precedent that a failure to seek consent is a breach of international law.

In the permitting process for actual mining, the requirements regarding consultation and compensation for damages, the usufruct rights of reindeer herding Sámi are also

\footnotetext{
${ }^{8}$ Note that some areas may have special cultural values for specific groups, such as the Sámi. Thus, indigenous cultural interests in land can be site-specific non moveable.
} 
equally well protected as those of landowners. However, parity with landowners in this regard is insufficient in cases where significant impacts can be expected, and further measures would need to be introduced to reach the requirements of FPIC and the associated need to obtain consent. Again, the requirements that exist in terms of consultation fall upon the proposed mine operators, and not the state, and this issue also would need to be addressed. Furthermore, there is significant discrimination against Sámi rights holders when it comes to the issue of being able to have a share in the benefits of mining projects. Impacted reindeer herders have no such option, whereas landowners do. Lastly, the permitting processes do not normally include any consideration of social and/or cultural impacts, which is a clear shortcoming compared to what is required to be in line with the indigenous rights framework.

If mineral regulations were changed so that the Sámi reindeer herders were given parity with landowners, and the other shortcomings identified above would be addressed, the impacts on the mining sector could be fairly insignificant. This follows from mining creating large values but being a minor user of land. Thus, risks for significant negative impacts on mining do not constitute a strong reason for Sweden to not fully implement the indigenous rights framework and its requirements regarding FPIC. However, the same does not hold true for other significant sectors of the economy which use more extensive land areas. For these, parity between landowners and Sámi reindeer herders would entail a considerable transfer of resources and associated power to the relatively small number of Sámi that are members of a sameby. This suggests that calls for changes to be made specifically to mineral-related legislation to resolve wider indigenous land right issues are in part misguided. To resolve such wider objectives requires fundamental issues of how extensive and strong the Sámi's rights to land are. This is, in turn, no straightforward task, and a number of particularities may make it difficult to achieve. Those particularities include the following:

- Historic Sami land use have not been made extinct in any of its historic extension and, thus, that the areas of land potentially affected are very large.

- The Sami land rights that exist today are specifically tied to reindeer herding, which in turn means that most with Sami heritage face fundamental obstacles in taking part in any land restitution related processes.

- The history of dispossession of the Sami included periods when land and resources was shared with both Swedes and other minorities, which makes assigning land rights a complex and difficult process.

- The forces for assimilation have been strong and there are few areas where those who sustain Sami culture and traditions make up a more significant part of the population.

The ongoing efforts by the Swedish government to improve consultation with the Sámi and to review the reindeer herding law are unlikely to be sufficient to align Sweden with the international indigenous-rights framework. To achieve such an aim would require a more ambitious process - probably involving numerous court cases where historic uses of land are assessed, and land rights determined. Mining specific land use issues will be significant in such a process, but would not constitute a significant obstacle to progress, fundamentally due to the small areas that are being used for mining.

Open Access This article is licensed under a Creative Commons Attribution 4.0 International License, which permits use, sharing, adaptation, distribution and reproduction in any medium or format, as long as you give appropriate credit to the original author(s) and the source, provide a link to the Creative Commons licence, and indicate if changes were made. The images or other third party material in this article are included in the article's Creative Commons licence, unless indicated otherwise in a credit line to the material. If material is not included in the article's Creative Commons licence and your intended use is not permitted by statutory regulation or exceeds the permitted use, you will need to obtain permission directly from the copyright holder. To view a copy of this licence, visit http://creativecommons.org/licenses/by/4.0/.

\section{References}

Åren -v- SWE (2020). Opinion on Communication 54/2013: LarsAnders Ågren et al and Sweden, Committee on the elimination of racial discrimination (18 December 2020, (UN doc CERD/C/102/D/54/2013))

Anaya SJ, Rodríguez-Piñero L (2018) The making of the United Nations declaration on the rights of indigenous peoples. In: Hohmann J, Weller M (eds) The UN Declaration on the Rights of Indigenous Peoples: A Commentary. Oxford University Press, Oxford (GBR), pp 38-62

Baer L-A (2005) The rights of indigenous peoples - a brief introduction in the context of the Sámi international journal on minority and group rights 12:245-268 https://doi.org/10.1163/1571811057 74740589

Barelli M (2018) Free, prior and informed consent in the United Nations declaration on the rights of indigenous peoples Articles 10, 19, 29(2) and 32(2). In: Hohmann J, Weller M (eds) The UN Declaration on the Rights of Indigenous Peoples: A Commentary. Oxford University Press, Oxford (GBR), pp 247-269

Beland Lindahl K, Baker S, Rist L, Zachrisson A (2016) Theorising pathways to sustainability International journal of sustainable development and world ecology 23:399-411 https://doi.org/10. 1080/13504509.2015.1128492

Berg A, Östlund L, Moen J, Olofsson J (2008) A century of logging and forestry in a reindeer herding area in northern Sweden Forest ecology and management 256:1009-1020 https://doi.org/10. 1016/j.foreco.2008.06.003 
Brännström M, Allard C (2019) Samebyars avtalsrätt - en replik (Samebyar contract law - a reply). Svensk Juristtidning (swedish Law Journal) 2:165-169v

Cameron P, Stanley M (eds) (2017) Oil, Gas, and Mining. A sourcebook for understanding the extractive industries. World Bank, Washington DC

Carstens M (2016) Sami Land Rights: the Anaya REPORT and the Nordic Sami Convention. J Ethnopol Minor Issue Europe $15: 75-116$

Charters C (2018) Indigenous peoples' rights to lands, territories and resources in the United Nations declaration on the rights of indigenous peoples: Articles 25, 26, 27 and 10. In: Hohmann J, Weller M (eds) The UN Declaration on the Rights of Indigenous Peoples: A Commentary. Oxford University Press, Oxford (GBR), pp 395-424

Coates K, Favel B (2016) Understanding FPIC: From assertion and assumption on 'free, prior and informed consent' to a new model for indigenous engagement on resource development secondary understanding FPIC: from assertion and assumption on 'free, prior and informed consent' to a new model for Indigenous engagement on resource development. MacdonaldLaurier Institute, Ottowa

Concl Obs SWE CCPR (2016) Concluding observations on the seventh periodic report of Sweden secondary concluding observations on the seventh periodic report of Sweden. United Nations, Geneva (CHE)

Concl Obs SWE CERD (2018) Concluding observations on the combined 22nd \& 23rd periodic reports of Sweden secondary concluding observations on the combined 22nd \& 23rd periodic reports of Sweden. United Nations, Geneva (CHE)

Concl Obs SWE CESCR (2016) Concluding observations on the sixth periodic report of Sweden secondary concluding observations on the sixth periodic report of Sweden. United Nations, Geneva (CHE)

Downing T, Moles J, McIntosh I, Garcia-Downing C (2002) Indigenous peoples and mining encounters: strategies and tactics. International Institute for Environment \& Development, London

Dupuy K (2014) Community development requirements in mining laws The Extractive Industries and Society https://doi.org/10. 1016/j.exis.2014.04.007

Energimyndigheten (2020). www.energimyndigheten.se. Stockholm

Errico S (2018) Control over natural resources and protection of the environment of indigenous territories: articles 29, 30 and 32. In: Hohmann J, Weller M (eds) The UN declaration on the rights of indigenous peoples: a commentary. Oxford University Press, Oxford (GBR), pp 425-457

Gen Com 23 CCPR (1994) General comment no. 23: the rights of minorities (Art. 27) human rights committee, UN doc CCPR/C/21/Rev.1/Add.5

Gen Rec 23 CERD (1997) General recommendation XXIII: indigenous peoples committee on the elimination of racial discrimination, UN doc $\mathrm{A} / 52 / 18$, annex $\mathrm{V}$

Girjasmålet (2020). Girjasmålet (the Girjas case), Supreme Court Case T 853-18)

ICMM (2013) Indigenous peoples and mining position statement secondary indigenous peoples and mining position statement. London

ICMM (2015) Indigenous peoples and mining good practice guide secondary indigenous peoples and mining good practice guide. International Council on Mining \& Metals, London

ICMM (2020) Mining principles secondary mining principles. International council on mining \& metals, London

IFC (2012) Performance standard 7: indigenous peoples secondary performance standard 7: indigenous peoples. World Bank Group, Washington DC
IGF (2013) Mining and Sustainable development: managing one to advance the other secondary mining and sustainable development: managing one to advance the other. Intergovernmental Forum Secretariat (Foreign Affairs, Trade and Development Canada), Ottawa

ILA (2012) Rights of indigenous peoples secondary rights of indigenous peoples. Sofia

ILO 169 (1989) Convention concerning indigenous and tribal peoples in independent countries International Labour Organisation, 1650 UNTS 383 (in force 5 Sep 1991)

International Resource Panel (2020) Mineral resource governance in the 21st century: gearing extractive industries towards sustainable development secondary mineral resource governance in the $21 \mathrm{st}$ century: gearing extractive industries towards sustainable development. UN Environment Programme, Nairobi

Kitok - v- SWE (1988). Views on Communication 197/1985: Ivan Kitok and Sweden, Human rights committee (27 July 1988, UN doc CCPR/C/33/D/197/1985)

Kløcker Larsen R, Österlin C, Guia L (2018) Do voluntary corporate actions improve cumulative effects assessment?Mining Companies' Performance on Sami Lands. Extr Ind Soc 5:375-383

Kløcker Larsen R, Raitio K, Stinnerbom M, Wik-Karlsson J (2017) Sami-state collaboration in the governance of cumulative effects assessment: a critical action research approach Environmental impact assessment review 64:67-76 https://doi.org/10.1016/j. eiar.2017.03.003

Länsman -v- FIN (1994). Views on Communication 511/1992: Ilmari Länsman and Finland, Human Rights Committee (8 November 1994, (UN doc CCPR/C/52/D/511/1992))

Länsman -v- FIN (1996). Views on Communication 671/1995: Jouni Länsman and Finland, Human Rights Committee (22 November 1996, (UN doc CCPR/C/58/D/671/1995))

Länsman -v- FIN (2005). View on Communication 1023/2001: Jouni Länsman \& Muotkatunturi Herdsmen's Committee and Finland, Human Rights Committee (17 March 2005, (UN doc CCPR/C/83/D/1023/2001))

Lassila M (2018) Mapping mineral resources in a living land: Sami mining resistance in Ohcejohka, northern Finland Geoforum 96:1-9

Lawrence R, Åhrén M (2017) Ch 10 Mining as colonisation: the need for restorative justice and restitution of traditional Sami lands. In: Head L, Saltzman K, Setten G, Stenseke M (eds) Nature, temporality and environmental management: Scandinavian and Australian perspectives on peoples and landscapes. Routledge, London, pp 172-191

Lawrence R, Moritz S (2019) Mining Industry Perspectives on Indigenous Rights: Corporate Complacency and Political Uncertainty. Extract Indust Soc 6:41-49. https://doi.org/10.1016/j.exis.2018. 05.008

Lundmark L (2008) Stulet land: Svensk makt på Sámisk mark. Ordfront förlag AB, Stochholm

MAC (2019) Towards sustainable mining 101: a primer secondary towards sustainable mining 101: A Primer. Mining Association of Canada, Toronto

Mahuika-v- NZL (2000). Views on Communication 547/1993: Apirana Mahuika et al and New Zealand, Human Rights Committee (16 November 2000, UN doc CCPR/C/70/D/547/1993)

Mörkenstam U (2019) Organised hypocrisy? The implementation of the international indigenous rights regime in Sweden The international journal of human rights 23:1718-1741 https://doi.org/10. 1080/13642987.2019.1629907

Newman D (2017) Political Rhetoric Meets Legal Reality Secondary Political Rhetoric Meets Legal Reality. Macdonald-Laurier Institute, Ottawa

Ncp NOR (2016) Jijnjevaerie Saami village - Statkraft SCA Vind AB (SSVAB) Secondary Jijnjevaerie Saami village - Statkraft SCA 
Vind AB (SSVAB). Norwegian National Contact Point for the OECD Guidelines for Multinational Enterprises, Oslo

NRGI (2014) Natural resource charter secondary natural resource charter. Natural Resource Governance Institute, London

OECD (2016a) Collaborative strategies for in-country shared value creation secondary collaborative strategies for in-country shared value creation. Organisation for Economic Co-operation \& Development, Paris

OECD (2016b) Due diligence guidance for responsible supply chains of minerals from conflict-affected and high-risk areas secondary due diligence guidance for responsible supply chains of minerals from conflict-affected and high-risk areas. OECD Publishing, Paris

OECD (2017) Due diligence guidance for meaningful stakeholder engagement in the extractives sector secondary due diligence guidance for meaningful stakeholder engagement in the extractives sector. Organisation for Economic Co-Operation and Development, Paris

OECD (2020) Guiding principles for durable extractive contracts secondary guiding principles for durable extractive contracts. Organisation for Economic Co-operation \& Development, Paris

Ominayak -v-CAN (1990). Views on communication 167/1984: Chief Ominayak \& Lubicon Lake Band and Canada, Human Rights Committee (26 Mar 1990, (UN doc CCPR/C/38/D/167/1984))

Persson B (2007) Sápmi förr \& nu. HS Copy Media \& Service, Luleå (SWE)

Persson S, Harnesk D, Islar M (2017) What local people? Examining the Gállok Mining Conflict and the Rights of the Sámi Population in Terms of Justice and Power. Geoforum 86:20-29

Poma Poma -v- PER (2009). Views on communication 1457/2006: Ángela Poma Poma and Peru, Human Rights Committee (24 April 2009, (UN doc CCPR/C/95/D/1457/2006))

Raitio K, Allard C, Lawrence R (2020) Mineral extraction in Swedish Sápmi: the regulatory gap between Sami rights and Sweden's mining permitting practices. Land Use Policy 99:105001. https:// doi.org/10.1016/j.landusepol.2020.105001

Samer (2020) www.samer.se.

Sametinget (2014) Sametingets syn på mineraler och gruvor i Sápmi (Sami Parliament's view on minerals and mines in Sápmi). Kiruna (SWE)

Sametinget (2020) Sámediggi.

SCB (2020) SCB.se. Solna (SWE)

SFS (1972) Expropriationslag (The expropriation law) 1972:719

SFS (1991) Minerallagen (The mineral law) 1991:45

SFS (1998) Miljöbalken (The environmental code) 1998:808

SGU (2016) Vägledning för prövning av gruvverksamhet. Dnr 3111808/2014 SGU-rapport 2016:23

SGU (2020) Årsredovisning 2020.

Southalan J (2012) Mining law and policy: international perspectives. Federation Press, Sydney (AUS)

SWE Gov (2015) Samerna - ett ursprungsfolk i Sverige. Frågan om Sveriges anslutning till ILO:s konvention nr 169 (The Sami - an Indigenous people in Sweden. The question of Sweden's accession to ILO Convention n169).

SWE Gov (2019) Konsultation i frågor som rör det samiska folket (Consultation in issues that concern the Sámi). Government of Sweden, Stockholm

SWE Plmnt (1976) Om insatser för samerna (Regarding measures for the Sami). Riksdag (Swedish Parliament), Stockholm
SWE Plmnt (2004) Ändringar i minerallagen (Changes in the Mineral Act). Riksdag (Swedish Parliament), Stockholm

SWE Plmnt (2010) Lag om ändring i regeringsformen (law on changes in the constitution). Stockholm

SWE Plmnt (2012) Undersökningstillstånd och arbetsplaner (exploration concessions and work plans). Stockholm

Tarras-Wahlberg NH (2014) Social license to mine in Sweden: do companies go the extra mile to gain community acceptance? Mineral Economics: Raw Materials Report 27:143-147

Torp E (2018) Samebyars avtalsrätt (Samebyar contract law) Svensk Juristtidning (Swedish Law Journal) 9:749-758

UN, (2007) Official Records, Sixty-first session, 107th plenary meeting. United Nations, New York

UN (2011) Guiding principles on business and human rights: implementing the United Nations "Protect, respect and remedy" framework secondary guiding principles on business and human rights: implementing the United Nations "protect, respect and remedy" framework. United Nations Human Rights Council, Geneva (CHE)

UN (2013) Extractive Industries and Indigenous Peoples Secondary Extractive Industries and Indigenous Peoples. Human Rights Council, Geneva (CHE)

UN (2016) The human rights situation of the Sami people in the Sápmi Region of Norway, Sweden and Finland Secondary The human rights situation of the Sami people in the Sápmi Region of Norway, Sweden and Finland. Human Rights Council, Geneva (CHE)

UN (2020) Report of the working group on the universal periodic review: Sweden secondary report of the working group on the universal periodic review: Sweden. United Nations, Geneva (CHE)

UNDP (2018) Extracting good practices secondary extracting good practices. UNDP and Swedish Environmental Protection Agency, New York (USA)

UNDRIP (2007) United Nations declaration on the rights of indigenous peoples UN General Assembly, UN doc A/RES/61/295

UNEP (2018) Managing mining for sustainable development: a sourcebook secondary managing mining for sustainable development: a sourcebook. United Nations Development Programme, Bangkok

Vapsten - v- Vapsten (2020). Vapsten lappby vs Vapsten sameby, Lycksele District Court case no. T 329-17)

Warden-Fernandez J (2001) Indigenous communities and mineral development secondary indigenous communities and mineral development. International Institute of Environment and Development, London

Wilson E (2019) What is benefit sharing? Respecting Indigenous Rights and Addressing Inequities in Arctic Resource Projects. Resources 8:74-97

World Bank (2016) Environmental and social framework secondary environmental and social framework. International Bank for Reconstruction and Development, Washington DC

Young S (2019) Indigenous peoples, consent and right: troubling subjects. Taylor \& Francis Group, Milton (GBR)

Publisher's note Springer Nature remains neutral with regard to jurisdictional claims in published maps and institutional affiliations. 